\title{
Extension for the Accademia di Brera at the Farini Marshalling Yard in Milan: The Architecture of the Campus and Spaces Frames for Teaching
}

\section{Luca Monica, Luca Bergamaschi, Giovanni Luca Ferreri, Paola Galbiati and Massimiliano Nastri}

\begin{abstract}
A study of the architectural tradition of the types and spaces used to teach fine arts underlays the research to develop the Accademia di Brera project at the Farini marshalling yard, a brand-new campus for the arts as part of the urban regeneration of the whole of the former marshalling yard area. The system, which uses different varieties of newly built multiple teaching spaces, is inserted into the existing long galleries which feature frame construction.
\end{abstract}

Keywords University campus architecture $\cdot$ Academies of art $\cdot$ Architectural composition $\cdot$ Urban design $\cdot$ Building types

\section{Among the Academies of Europe}

There are many reasons why the Brera Academy of Fine Arts needs more room, in a new, more rational, separate site; a theme that has traveled its history, with various projects throughout the twentieth century in common with many other European academies.

Most certainly we can thank the beautiful book Academies of Art. Past and Present by Pevsner (1940) for a modern recognition of the European identity of a social institution which was long the cornerstone of the artistic and cultural formation and ferments in Western thought throughout the nineteenth century. Albeit in the complex variety of institutional roles and even in its controversial role as a guide, between "academy" and "anti-academy", Pevsner's text succeeded in building a profile that recognizes the common characteristics of the long course of the social history of art,

L. Monica ( $\varangle) \cdot$ M. Nastri

Architecture, Built Environment and Construction Engineering-ABC Department,

Politecnico di Milano, Milan, Italy

e-mail: luca.monica@polimi.it

L. Bergamaschi

Università IUAV, Venezia, Italy

G. L. Ferreri - P. Galbiati

Milan, Italy

(C) The Author(s) 2020

S. Della Torre et al. (eds.), Buildings for Education, Research for Development,

https://doi.org/10.1007/978-3-030-33687-5_22 
split among decidedly European contexts in the large capitals and the more marginal provinces.

Pevsner's story extends up to the threshold of the Modern Movement, to the "awakening of the industrial arts" at Gropius' Bauhaus, but could ultimately continue up to our own times, given that today many of these academies still play an active and identifiable role within a common European history, which, although arguably lacking a reference community policy, has encouraged local developments that are not always easily comparable.

Looking at it today, that network of exchanges which united the academies in Europe and across the world certainly ceased to exist as soon as the educational statutes evolved in line with the positions of higher university education in different ways from one country to the other.

These all tend to be found in historical contexts and buildings of maximum value, also thanks to their inaugural layouts and spaces (a school, workshop and museum all at the same time). Secondly, the academies possess and defend a historical-artistic heritage of enormous value still alive and well among their spaces (Cassese 2013).

\section{The Farini Marshalling Yard and an Architectural Research Tradition}

The Northwest trajectory was recognized by many as one of the most important constitutive elements and a vital component in the system of radial trajectories which formed the layout of modern Milan, based on real, formally complete "linear cities". Its high potential for transformation, as well as its extraordinary endowment of relations and infrastructure systems towards the productive "hinterland", resisted the slow process of welding the urban expansion fabric together (Canella 1981).

Boasting important architectural and urban projects in the best tradition of Milanese rationalism, this was precisely the terrain for the application of a number of research and teaching theories of the Faculty of Architecture of Milan.

With the decommissioning and consequent displacement of the Trade Fair quarter to the outlying zone of Rho-Pero, the propulsive sense of the Sempione-Fair axis was partially shut down, only a few years earlier still fixed in the collective imagination and in its functions as a management centre as an area perennially available for transformation, a sort of palimpsest open to the dynamics of economic territorial development, through its exceptional, strongly experimental architecture.

In the meantime, other research goals had found an important parallel in the Garibaldi-Bovisa axis, where, in addition to the great accessibility given by the historical trajectories of the railway lines, the dismantling of the production base was producing a gradual transformation of the area.

The first educational and research projects were developed back in the 1970s by Guido Canella's group (Variations on the Wolkenbügel (cloud-hangers) of El 
Lissitsky-Mart Stam, 1974), for a new technology department of the Polytechnic at Bovisa, a first anticipation of the future detachment (Fiorese 1984).

Experiments which followed were by projects for the exhibition Le città immaginate at the 17th Milan Triennale (1987), with projects for the Bovisa Polytechnic by Guido Canella, or for a big service connector and park at the Farini marshalling yard by Gustav Peichl, and the first polytechnic masterplan for a new campus (1990) designed by Antonio Monestiroli, with the buildings designed by teachers of architecture from the Faculty itself.

On the Garibaldi-Farini-Bovisa axis, the ex-marshalling yard presents itself as an important large "vuoto urbano" (urban vacuum) to be given over to a metropolitan park with amenities. The first thesis came in 1978, Milano-Bovisa: riconfigurazione dello storico porto in terra metropolitano dal recupero del Cimitero Monumentale (supervised by A. Acuto, G. Canella), followed by the project by Vittoriano Viganò in 1979 for the Garibaldi Station area extended as far as the marshalling yard, part of a mega-structure with a linear frame.

In 2009, the School of Architettura Civile along with the Municipality of Milan, in view of the future Accordo di Programma, addressed these issues at a workshop entitled Milano. Scali ferroviari e trasformazioni urbane. If, on one hand, the various hypotheses tried to make the property imbalance indicated by the agreement compatible, other research groups tried to continue the hypothesis of the urban trajectory and the linear business district, extended to $10 \mathrm{~km}$ from Garibaldi to Fiera-Expo, recovering the monumental sense of its architecture and landscape, as the projects by the groups of Canella and Bordogna (Protasoni 2012), through a series of strategic functions. Following that, the research project La parte elementare della città. Progetti per Scalo Farini a Milano (A. Monestiroli, R. Neri, A. Dal Fabbro and others) concentrated on the quality of the urban architectural project for a residential district (Neri 2014).

With regard to the extension for the Accademia at the Farini marshalling yard, proposals were developed as alternatives to the original Grande Brera project which wanted to allocate the Accademia into the barracks in Via Mascheroni-Monti (Monica 2013, 2014; Bon Valsassina 2014). Among the first works, it is worth recalling the thesis entitled Per Campus Brera un nuovo modello teresiano. Scalo Farini Milano (supervised by G. Fiorese in 2010) and other academic works (Monica et al. 2015), later shown at a larger exhibition in the Accademia itself in 2016 (teachers M. Dezzi Bardeschi, G. Guarisco, L. Monica, A. Torricelli), which was followed by an in-house debate which had already begun at the Accademia (Bonini 2019, p. 8; Cusatelli 2019; Monica 2017; Bianchi and de Lillis 2017).

The aim of these proposals for the Farini marshalling yard, for a higher education establishment such as an academy of art, was to seek an urban regeneration process that was compatible with the assumed property imbalance envisaged in the Accordo di Programma, of which today only in the light of the first results of the design contest for the Masterplan, we could glimpse the concrete and predictably reductive directions compared to its premises and possibilities which the research had theorized (OMA and Laboratorio Permanente 2019). 
Looking then at the long tradition of architectural research and projects around the theme of urban recovery in the Farini marshalling yard, the conviction remains today that the establishment of strategic functions on a metropolitan and territorial scale_-public architecture for services-remains the necessary point of departure for this renewal.

\section{The New Campus for the Artists' Community of Brera}

The prominent aspect of the great goods depot at the Farini marshalling yard is its large overall dimension and its typological and structural uniqueness, constituted by two galleries of around $350 \mathrm{~m}$ in length, which the original installation was based on before 1914, made of reinforced concrete using a typical frame structure. The serial nature of the internal structure, clearly visible in the full length of the two galleries, endows the building with an unusual and modernly monumental scale.

The entire area of the Farini marshalling yard is part of the Accordo di Programma arranged by the Municipality of Milan which covers the part of the building of the former goods depot intended for the Accademia di Brera. In the future urban development of the area, it is planned to expand the "Campus of the Arts", which could actually be considered as a relatively autonomous part with respect to the overall design of the large park and the predictable residential district. An autonomy guaranteed especially by its strategic public function for the city (a university campus) is in itself able to act as a solvent in a hub interconnecting the neighborhoods and multiple amenities surrounding the former yard.

This first scheme therefore involves the entire yard when it comes to organizing the Brera Campus, which will proceed in phases with a first settlement in the former goods depot, taking advantage of the full occupation of the entire former depot, and considering its shared use with the public spaces for exhibitions, leisure activities and services for the area, thus preserving its architectural and monumental unity with respect to the entire area of the yard (Figs. 1 and 2).

A new building will be added which will be taller, to contain all the functions that the Accademia requires to complete the university complex (service spaces for studying, lecture rooms, departmental offices for teachers and ateliers), and different in type and spaces, forcing the empty spaces intended as an aesthetic reserve, perceptible from the large ex-depot now belonging to the Accademia (Fig. 3).

\section{Frames, Urban Settings and Suspended Images}

Following a hypothetical ideal route, visitors should reach the new spaces of the Accademia di Brera at the Farini marshalling yard by arriving from the Monumental Cemetery complex. On entering they would be standing in front of the monument built in 1946 by the BBPR group of Milanese architects in memory of those deported 
to concentration camps. Precisely this frame, resolved in a cube, marks the stopping point of an independent path of Italy's figurative culture; after this, the suspension of the search for a city moral expressed itself in addition to the certainties of the aesthetic consent "without a relationship with the taste of the majority" (Persico 1934, 1964, p. 255).

This structure at the cemetery appears as a fragment of what had already been tried out in 1934 by Edoardo Persico and Marcello Nizzoli for the Medaglie d'Oro room at the Esposizione Aeronautica Italiana in Milan's Palazzo dell'Arte, and that same year for an advertising structure erected at the crossing inside the Galleria Vittorio Emanuele II, using a framework of Mannesmann tubes.

The frame structure therefore becomes a device for fine-tuning the relationship between dimensional aspects and habitability.

These installations are "lyrical visions of construction" (Veronesi 1953), visions that continue the investigation into the city and its changes. This work can be traced back to the itinerary of pictorial research which has always related with the meeting between the urban dimension and temporality by tabulating symbols, allegories and formal abstractions. In fact, as far back as the fourteenth century-even before the awareness given by the science of perspective had arrived-the city was depicted by arranging human vicissitudes and urban sequences on superposed, occasionally ambivalent planes. In these representations, architecture was the limit condition between public experience and family life.

Perspective, seen as a representation of objective reality, was demonstrated through a mix of empiricism and esotericism. With the precision of the vanishing point, the works of architecture were conditioned by the choice of the viewpoint and had also to take immediately account of their constructive datum.

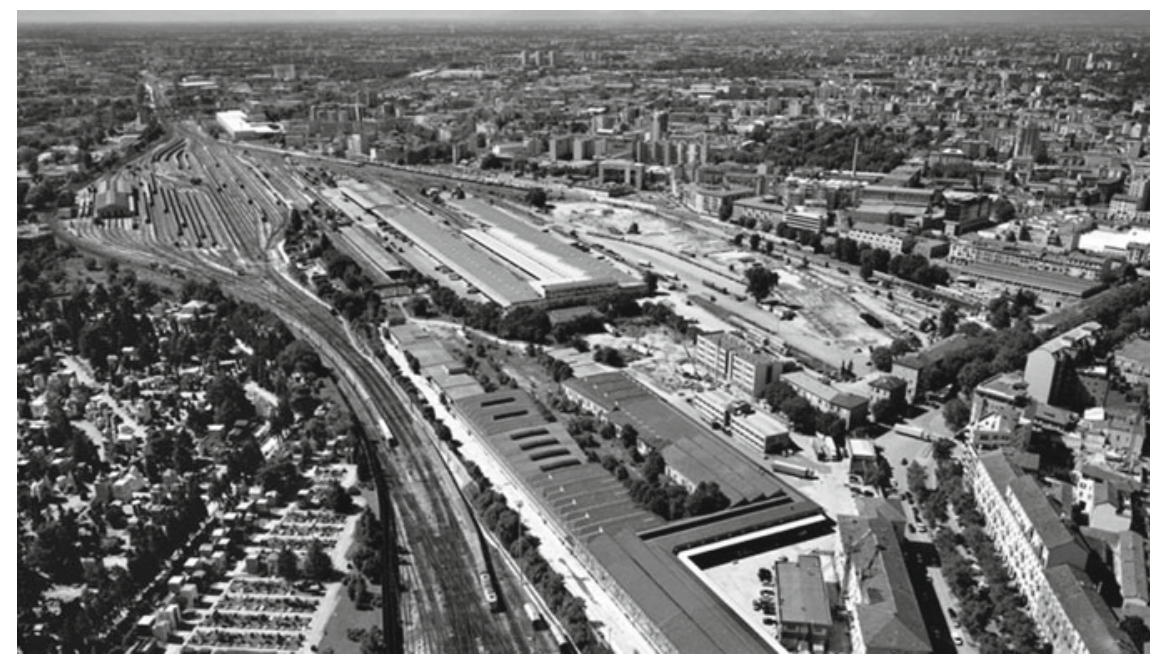

Fig. 1 Aerial view of the Farini marshalling yard, 1998. Photo S. Topuntoli 

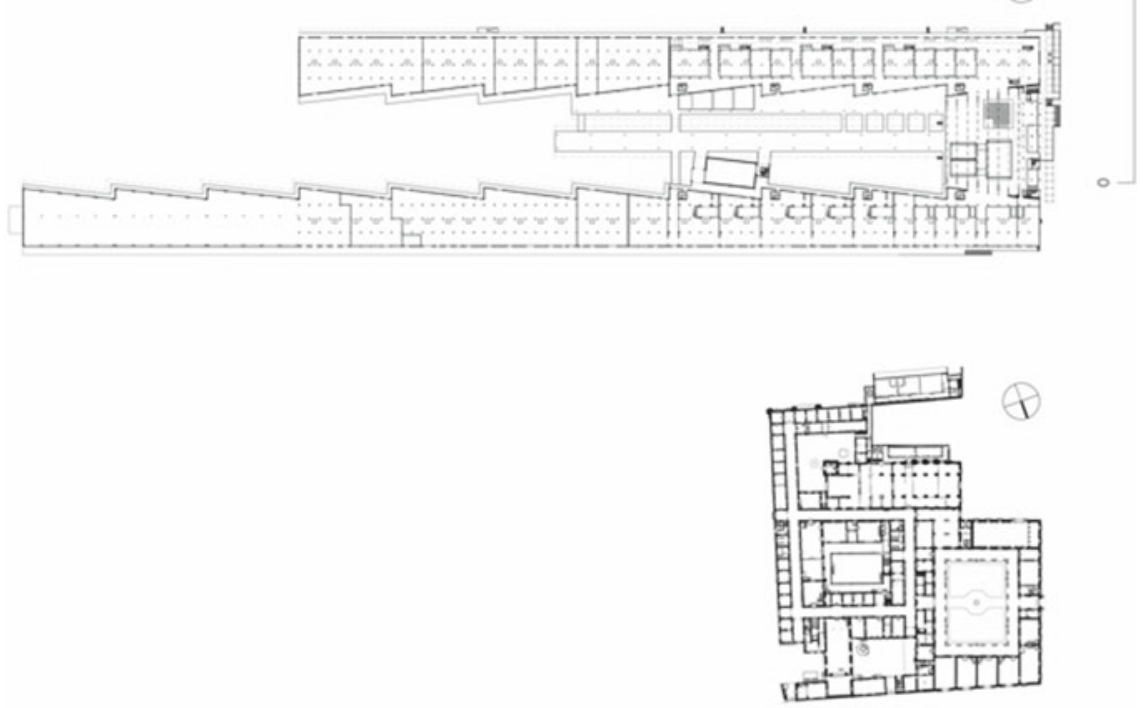

Fig. 2 Plans at the same scale of the Palazzo di Brera and the former goods depot at the Farini marshalling yard

For the group of rationalist architects who gravitate around the Milanese area, the frame is translated by urban civilization and almost no longer belongs to construction technique. Lines "give the integral form needed for all things", to paraphrase Roberto Longhi.

It was none other than Canella who related the work of the rationalist Milanese architects who gravitated around the figure of Edoardo Persico to the design styles worked on by Longhi, in a lesson on the poetics of Ignazio Gardella (Canella 1999).

Precisely this integrity of form - central to the examples we have mentionedleads us to prepare a structure not yet compromised by material aspects in our own intervention: i.e. a clean-cut structure delimits the public space from the surrounding buildings. This is an element under which it is possible to linger awhile, discuss, and build relationships.

Arriving in the area of the Farini marshalling yard, during the first on-site visits to the old buildings to be converted, it came to us that it would be necessary to fix its dimension through an ephemeral and reversible element. Precisely in this research on the dimension, the reasons behind the architectural intervention for the settlement of the educational activities lay. The structure testifies to the fact that, in addition, something is happening: beyond that diaphragm, the place needs to be populated. Behind that declaredly ephemeral deck, it is necessary to settle those activities of the Accademia currently deployed among different temporary places. 


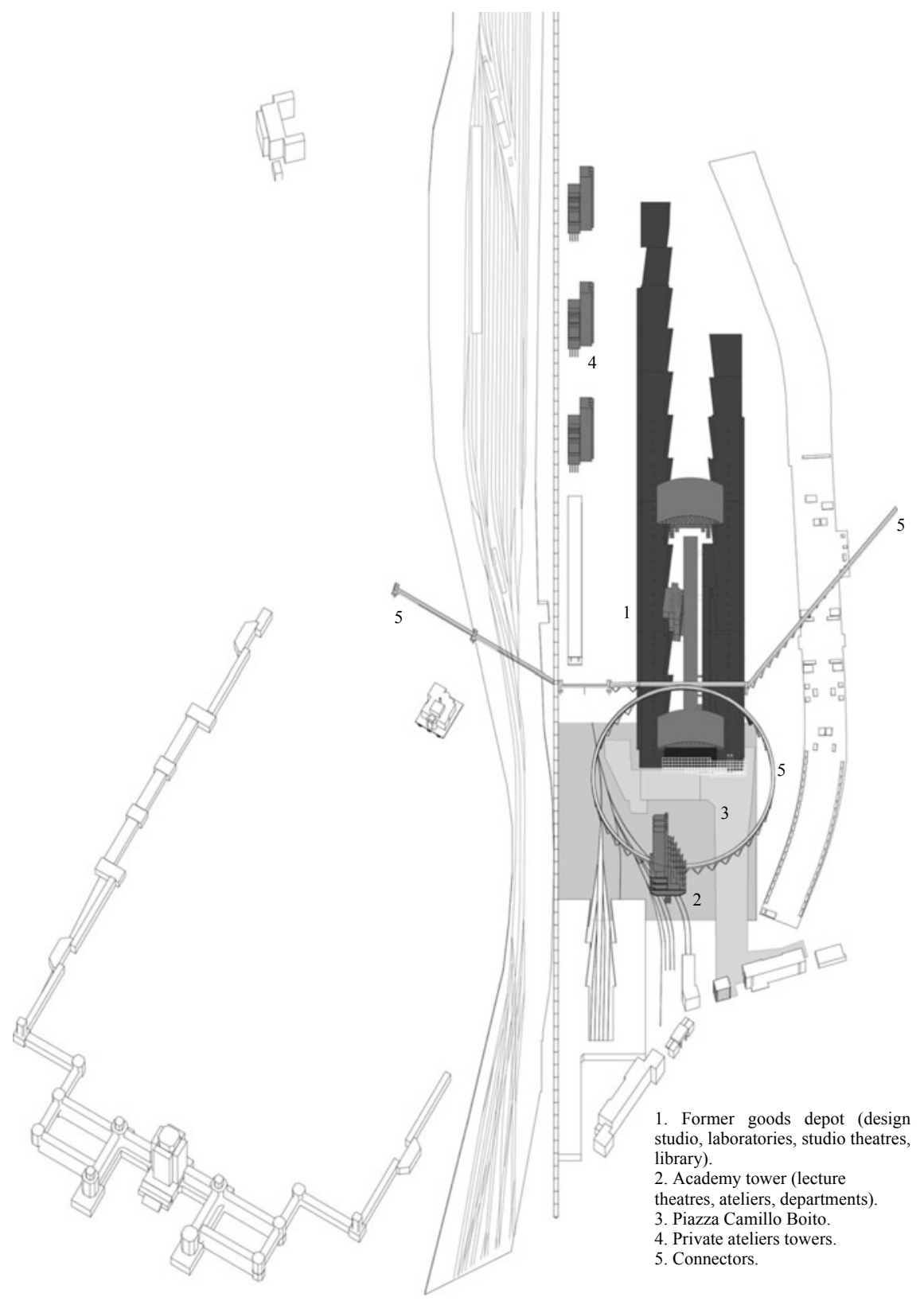

Fig. 3 Research group: L. Monica, M. Acito, L. Bergamaschi, S. Cusatelli, G.L. Ferreri, P. Galbiati, G. Guarisco, M. Nastri, M. Rajabi, Campus for the Arts of Brera. Extension of the Brera Academy at the Farini marshalling yard: General plan 
This figure is the minimum construction datum on which to hang, suspend and superimpose themes or even better, to write-always in the form of an allegorywords like civilization, art, taste, aesthetics and morals.

\section{Inside the Continuous Monument}

The splitting up of the teachings of the Accademia di Brera among multiple locations has increased over the years ever since its evolution toward disciplines which have extended artistic practices in addition to the traditional fundamental ones based on the art of drawing. This is a lengthy process, which certainly began with the new cultural system imposed by Camillo Boito at the Accademia between the end of the nineteenth century and the beginning of the twentieth century, accompanied by the maturing of disciplines related to contemporary industrial arts and to restoration, which might never have found a place in the old Brera building, but arguably more suitable spaces in the oft-cited capannone (shed) (see G. Guarisco in this same volume).

Everything began from that Brera building which saw the birth of this institution in 1776, whose distinctive feature from the beginning was the coexistence of multiple activities. A birth that was far from precocious among the academies of art in Italy and in the rest of Europe, but in an absolutely unique and original context, where, in the monastic reality of the original Jesuit College layout, various educational and research institutions, museums, and conservation workshops coexisted.

Starting from the first transformations and additions of spaces from college to academy designed by Giuseppe Piermarini, there were proposals and second thoughts on the most suitable location for each activity. With time, many other variations and internal additions followed, from the construction of the so-called "Hayez Classrooms" (architect G. Voghera, 1852-1857), the pavilion in reinforced concrete to exhibit the plaster casts, conceivably the first in Milan (architect A. Brusconi, 1900), then the didactic library (architect L. Patetta, 1984), up to the apparently incongruous but modern system of mezzanines (Fig. 2).

Today, therefore, it is no longer possible to postpone the reunion of the new seats in a "new monument" that can house spaces more suitable for contemporary teaching methods, divided into two large typological categories, effectively organized in the two grand arcades recovered inside the ex-depot. In fact, these two distribution lines organize both the changed spatial needs and the layout of the traditional teachings (workshops for the various sculpture techniques), and the design laboratory activities (in spaces typologically assimilable to those of schools of architecture, design, etc.).

A third distribution line, that of the free connecting spaces, assumes a further function as a place for individual students to study, share and produce autonomously.

The construction of a common minimum technical-functional denominator could indeed encourage the various forms of operations through simple modular construction elements, the "frames", partly transparent and partly not repeatable and variable with changing needs, and able to maintain one of the typological characteristics which distinguish the former railway depot: the unity of the internal space, also of 
a certain quality and not devoid of figurative suggestion, the symbol and monument of a different kind of industriousness, apparently equally disordered, but capable of restoring a sense of community in the difference, as in a sort of "continuous monument" (Figs. 4-6).

\section{Technique and Construction of Internal Framed Partitions}

The study of internal partition systems to fill the two arcades devoted to teaching envisages the design of an independent, self-supporting metal frame with respect to the concrete structure of the building, both for the heavy instrumental laboratories and the light teaching laboratories.

The pattern of modular frames, oriented as the main and secondary load-bearing systems, is related to research and design experimentation as well as contemporary construction, through the definition of:

- stretchers superimposed on the existing apparati, according to a relation of transition with the tectonic, spatial and connective structures in a pervasive form and through fragments, repeated serially in a perspective succession;

- conceptual installations that reveal a functional and visual permeability, as occasions for symbiosis with the existing structure;

- dematerialization of classroom-containers, defined by filters and passages between diversified geometric and dimensional perceptions articulated by a linear design.

The composition of the typological units of the teaching spaces and their structural elements is based on vertical linear frame apparati in metal (steel), comprising:

- normal closure profiles (transparent glass and opaque wooden panels);

- a succession of service modules with shelves;

- realization of the top section as a mezzanine;

- aggregation of flights of stairs;

- a connection with the continuous horizontal plane-route as a suspended walkway, intended to house the study activities of the teachers.

\section{References}

Bianchi F, de Lillis L (eds) (2017). Spazio Accademia. Tra espansione e salvaguardia di un'identità culturale. Seminario di studio docenti-studenti. Accademia di Belle Arti di Brera, Milano

Bonini G (2019) Per una grande Accademia. In: Cusatelli S (ed), op. cit., p 8

Bon Valsassina C (2014) Il caso Palazzo Citterio, Skira, Milano

Canella G (1981) Il "Genius loci” della Direttrice Nord-Ovest. In: Hinterland, no 19-20, pp 80-91 

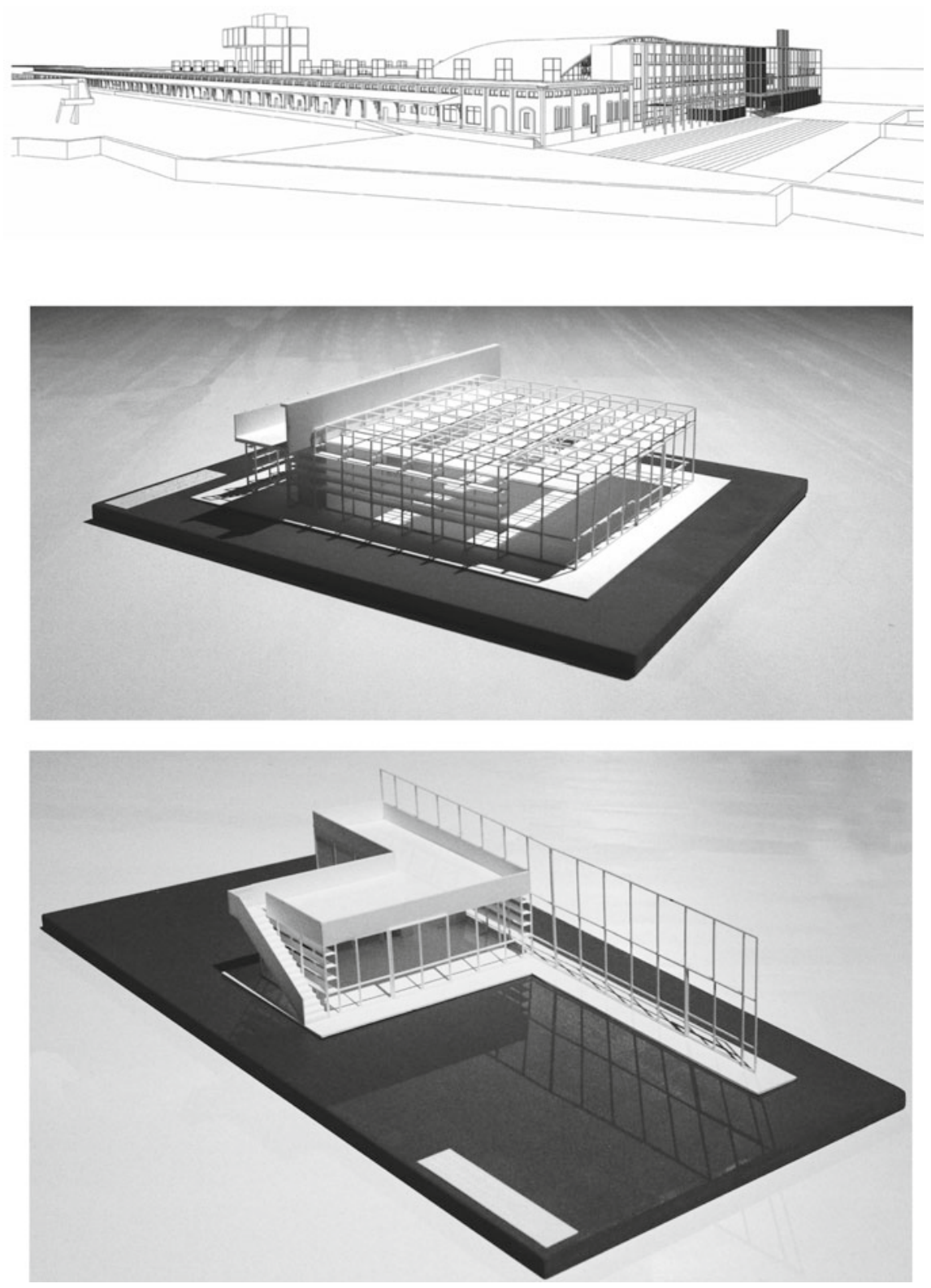

Figs. 4-6 Research group: L. Monica, M. Acito, L. Bergamaschi, S. Cusatelli, G.L. Ferreri, P. Galbiati, G. Guarisco, M. Nastri, M. Rajabi, Campus for the Arts of Brera. Extension of the Brera Academy at the Farini marshalling yard: View of the entrance structure; Scale models of the design studio and laboratories 
Canella G (1999) Ignazio Gardella: le figure e le città, lezione, 2 giugno 1999, preprint 2000, Politecnico di Milano, now in Architetti italiani nel Novecento, ed by E Bordogna, Christian Marinotti, Milano 2010, p $289 \mathrm{ff}$

Cassese G (2013) Accademie patrimoni di belle arti, ed by, Gangemi, Roma

Cusatelli S (ed) (2019) Campus delle Arti di Brera. Ampliamento dell'Accademia allo Scalo Farini. Indirizzi di un progetto architettonico, Mimesis, Milano

Fiorese G (ed) (1984) MZ7. Milano Zona sette Bovisa Dergano. ICI-Comue di Milano, Milano

Monica L (2013) Le architetture per l'ampliamento dell'Accademia di Brera. Antecedenti e nuove ipotesi all'Ex Scalo Farini. In: Scarrocchia S (ed) Per Brera Sito Unesco, Accademia di Belle Arti di Brera, Fondazione Cariplo, Edizioni Sestante, Bergamo, pp 99-113

Monica L (2014) Brera. Dove? Nota sulle recenti vicende intorno Palazzo Citterio, le ipotesi per le ex Caserme di via Mascheroni a Milano e la necessità di una istruttoria per l'Accademia di Belle Arti, "Ananke", no 71, pp 41-46

Monica L, Cusatelli S, Ferreri GL, Guarisco G, Galbiati P, Scarrocchia S, Rajabi M et al (2015) Per l'ampliamento dell'Accademia di Brera. Ricerche progettuali. Politecnico di Milano e Accademia di Belle Arti di Brera, Mimesis, Milano

Monica L (2017) Diario breve di una ricerca universitaria per l'ampliamento dell'Accademia di Brera. In: Bianchi F, de Lillis L (eds) op. cit., pp 15-17

Neri R (ed) (2014) La parte elementare della città. Progetti per Scalo Farini a Milano, Lettera Ventidue, Siracusa

OMA and Laboratorio Permanente (2019) Design project "Per la trasformazione e rigenerazione urbana ex scali ferroviari Milano Farini e San Cristoforo". http://www.scalimilano.vision/concor so-scalo-farini/il-team-oma-e-laboratorio-permanente-e-il-vincitore-del-masterplan-concorsofarini/. Accessed 21 June 2019

Persico E (1934) Capocronaca dell' architettura, now in Tutte le opere (1923-1935), vol II, ed by Veronesi G, Comunità, Milano 1964, p 255

Pevsner N (1940) Academies of Art. Past and Present, Italian edition, Le accademie d'arte. Einaudi, Torino 1982

Protasoni S (ed) (2012) Milano scali ferroviari. In: Workshop della Scuola di Architettura Civile. Libraccio, Milano

Veronesi G (1953) Difficoltà politiche dell' architettura in Italia, 1920-1940. Tamburini, Milano

Open Access This chapter is licensed under the terms of the Creative Commons Attribution 4.0 International License (http://creativecommons.org/licenses/by/4.0/), which permits use, sharing, adaptation, distribution and reproduction in any medium or format, as long as you give appropriate credit to the original author(s) and the source, provide a link to the Creative Commons license and indicate if changes were made.

The images or other third party material in this chapter are included in the chapter's Creative Commons license, unless indicated otherwise in a credit line to the material. If material is not included in the chapter's Creative Commons license and your intended use is not permitted by statutory regulation or exceeds the permitted use, you will need to obtain permission directly from the copyright holder.

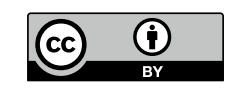

